1967 with the overall objective of helping all children "to get to grips with technology as a major influence in our society and as a result to help more of them to lead effective and satisfying lives". A working paper (No. 18: Technology and the Schools, HMSO, 5s.) which has just been published describes the present situation in schools and what Project Technology is all about.

The project is involving more than 600 schools in the preparation of a wide range of teaching material, in co-ordinating the general efforts and bringing outside organizations - universities, colleges, industry and other schools-into the scheme. Run by Mr Geoffrey Harrison and his assistants from the Loughborough College of Education, the project team also has many field workers - teachers who will be working on actual teaching material. The schools involved will either be trying out new material or will be providing advice as consultative schools; in addition, any schools which are interested in the project can receive advice on how best to present technology to the children. The vital part of the whole project is the practical side, with school children devising their own experiments and apparatus. The working paper gives many examples of projects which have been devised so far. Project Technology aims to provide boys and girls of all ages and abilities with an opportunity of developing talents other than the academic ones which are demanded by the traditional examinations. The problem is that it is difficult for an outsider to gauge a pupil's ability from the project work which has been done.

Regional groups are being organized for discussions and encouragement of links with universities and industry. Contact between individual teachers in schools involved in the scheme will be maintained in this way and schools outside the scheme will be encouraged to participate through these regional groups. The knowledge and attitudes of teachers are obviously important in projects of this kind, and it is hoped that universities and training colleges will develop courses which will provide the right background for future teachers. Help from industry is being sought in the form of equipment, either lent or given, in-service industrial experience for teachers, or, of course, money. The project has set its sights high and co-operation from a large number of people will be necessary for its success. To help it on its way the Schools Council is providing $£ 180,000$ for the first 3 years and the possibility of extension of the project will be considered in 1969 .

\section{More Buses, Less Bustle}

Journey times in central London would bo significantly reduced if private cars were replaced with buses, according to a study by Dr F. V. Webster of the Ministry of Transport (Road Research Laboratory Report $L R$ 165). A system relying solely on double-decker buses would be $£ 20$ million a year cheaper to run than the present mixture of buses and cars, most of the saving accruing from the cost of passengers' time. Although based on figures from London's traffic, the results of the study are probably also relevant to other large cities.

Passenger mileage during peak hours in central London is carried by a mixture of buses (73 per cent), private cars (22.5 per cent) and motor-cycles $(4.5$ per cent). The remainder of the traffic consists of taxis
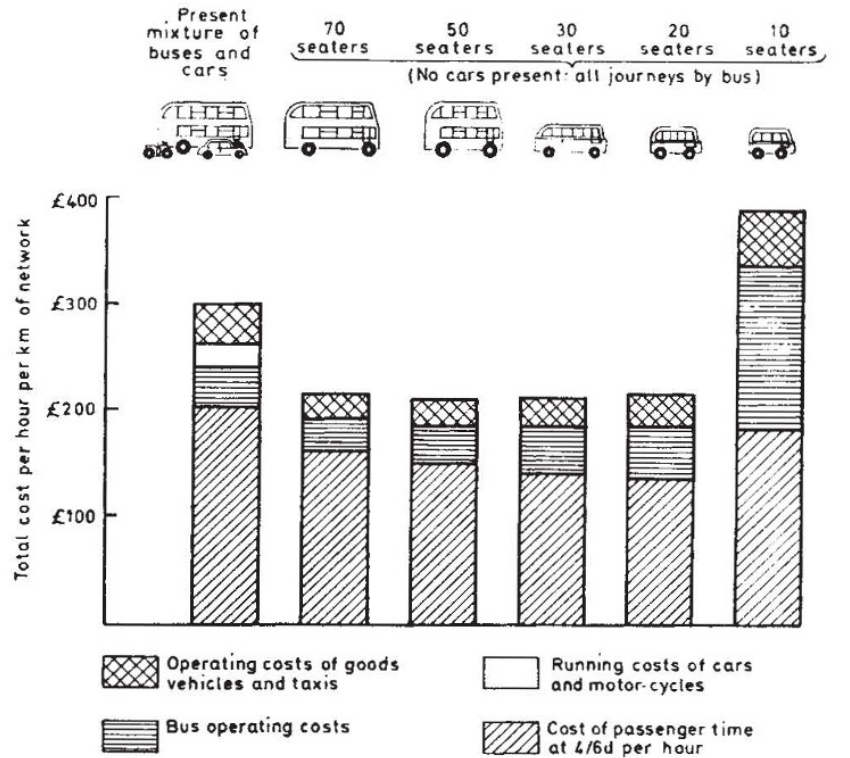

Costs (including passengers' time) of various bus systems.

and goods vehicles. Leaving the taxis and goods vehicles as they are, Dr Webster has considered the economic effects of removing the private cars from the roads and filling the gap with various systems of buses.

$$
\begin{aligned}
& \text { MOIRNEY TIMES (MINUTES) WITH PRESEN' AND BUS-ONIY } \\
& \text { SYSTHMS FOR 1, } 3 \text { AND } 5 \text { MILA JOURNHYS } \\
& \text { Present bus/car mixture } \\
& 1 \text { mile } 3 \text { miles } 5 \text { miles } \\
& 23 \quad 45 \quad 67 \\
& \text { Medium huses ( } 30 \text { seats) } \\
& 1 \text { mile } 3 \text { miles } 5 \text { miles } \\
& 14 \quad \begin{array}{lll}
38 & 43
\end{array}
\end{aligned}
$$

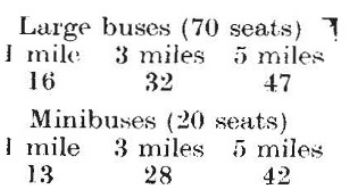

Bus systems considered ranged from the 70-seat double-decker bus in present use to 10 -seat minibuses. Calculations of average journey time were made for each system of bus, assuming that the freedom of the roads from private cars allowed optimum routing and frequency of the buses. The calculations (see Table) included estimates for the time spent walking to and from the bus-stop and in waiting for the bus. All systems gave a shorter average journey time than does the present one.

On the basis of journey times Dr Webster has calculated the operating costs of the various systems, valuing passengers' time at $4 s .6 d$. an hour. This figure derives from the assumption that 15 per cent of passengers are on business and worth $13 s$. $6 d$. an hour, and 85 per cent, travelling in their own time, are worth $3 s$. an hour. Other elements in the cost structure (see figure) are the operating costs of the various types of vehicle. Estimates for each system signify operating costs only, and do not include the capital cost of a new bus flect. Nor are such contingent factors considered as the decrease in revenue from petrol tax which would accompany the banning of private cars from central London.

The calculations suggest that all-bus systems would reduce the average journey time by up to one-third. Changing from the present system to all 70-seat buses would give a saving of $£ 80$ per hour per kilometre of road network. Assuming 200 kilometres of main road in central London, 5 hours a day of peak traffic and 
250 working days in the year, the total annual saving to be gained by the switch would be $£ 20$ million.

\section{Safety in High Blocks}

A PRELIMINARy report on the collapse of a 23 storey block of flats in East London last week confirms the opinion that the accident was caused by an explosion and not by any structural defect. The public inquiry into the collapse which will be held shortly will be headed by Mr Hugh Griffiths, recorder of Cambridge, and with him there will be a civil engineer and a fuel engineer. In the meantime, research in Britain into the safety of tall blocks seems to be non-existent. The Building Research Station, the only establishment in the country working entirely on building research, is not saying whether any research has been done there on the safety of tall blocks, in case the inquiry might be affected, but the Directorate of Research and Information (DRI) of the Ministry of Public Building and Works which has now undertaken a review of research in the construction industry, believes that no specific inquiries of the safety of tall buildings have been carried out.

Industrialized building methods for tall blocks have been in use for many years now, but the lack of any research into safety indicates that the dangers of such buildings have not been enough to warrant a research programme. If research is recommended by the public inquiry, this would come into the field of the DRI, which at present spends about $£ 130,000$ a year on building research. Established in 1962, the DRI is part of the Directorate General of Research and Development of the Ministry of Public Building and Works, with responsibility inside the ministry for policy on construction research and information. It also provides a background for the inquiries of the Construction Research Advisory Council under Sir Michael Cary, which was set up in November 1967 by the minister to advise on the best use of the national effort in building research. In the research field, as well as making a review of existing research and pointing out areas which would benefit from investigation, the DRI sponsors research in universities to the

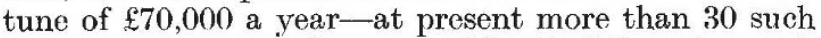
projects have been financed. The Building Research Station is now run through the DRI and of the $£ 60,000$ a year it spends, a quarter goes to universities for sponsored projects.

Information and industrial liaison are two important aspects of the DRI's work. As well as producing reports and advisory leaflets, the information group is hoping this year to begin publication of a quarterly journal on research and development in the construc. tion industry - no mean task, it seems, because it will have to be printed by the often slow-moving Stationery Office. Industrial liaison groups are dealing with building maintenance and computer applications. In the maintenance field the group is investigating such questions as the quantity and quality of maintenance work and the length of time the designers and constructors are responsible for a building -in Britain this is often only six months, while in France the period is more like ten years. The section dealing with applications of computers is to establish a construction industry computer centre which will be particularly useful for the smaller firms.

\section{Parliament in Britain}

$$
\text { by our Parliamentary Correspondent }
$$

\section{Nuclear Power}

There were a number of questions about the bid the UK Atomic Energy Authority has made to build a nuclear power station for Imatran Voima, of Finland. Mr Edmund Dell, for the Board of Trade, said that the Government was doing all within its power to support the AEA tender. The EFIA convention required that the award of the contract be made on commercial grounds, he added. Mr Wedgwood Benn, the Minister of Technology, said that the AEA and himself were completely convinced that the Steam Generating Heavy Water Reactor on offer in Finland was technically and commercially competitive with the other tenders. (Oral and written answers. May 15.)

\section{Grain Beetle}

WAS the Minister of Agriculture aware, Mr Kitson asked, that the saw-toothed grain beetle was not in this country 5 years ago, but that it was here now" What was he going to do about it? Mr John Mackie, for the minister, said that he had been accused of a number of things, but this was a new one. He did agree that the beetle was a pest, but said that its eradication was commercially impractical. Advice could be given for fumigation and the like, he suggested. (Oral answer, May 15.)

\section{Nuclear Fall-out}

Mr Nerl Marten asked the Prime Minister what would happen in the event of nuclear fall-out spreading as a result of a civil nuclear disaster. The Prime Minister replied that such an occurrence was highly improbable, but the related departments "would have a role to play in inter-rclated contingency plans". Mr Marten wanted to know what would happen when civil defence was disbanded next year. Mr Wilson suggested that the skill of the AEA could be provided in the event of such a disaster. (Oral answer, May I4.)

\section{Organ Transplants}

Mr Kenneth Robinson, the Minister of Health, refused to name the members of the Conference on Organ Transplantation. Nor would he list their qualifications, invite Members of Parliament to join the conference. publish a report of their deliberations, list the times, dates and places of the meetings, or say what arrangements he had made for the submission of written evidence to the conference. All he would do was to say that the conference would have a second meeting next month. (Written answer, May 14.)

\section{Rabies}

Mr John Mackie, for the Minister of Agriculture, said that the last case of the death of a dog from rabies in Britain was in 1949. A leopard cub had dicd in November 1965. Sir Richard Glyn, who asked for the figures, said that only three or four animals had developed rabies in quarantine in Britain in the past 20 years. and the great majority of animals coming into Britain capable of carrying rabies had not passed through quarantine. Mr Mackie said that the disease was a terrible one if it got into humans, and that no precautions could be too great. Dr John Dunwoody said that Britain was almost unique in having had no case of rabies for very many years. This showed the value of the regulations. Mr Mackie agreed. (Oral answer. May 15.) 